\title{
Identification of Endosymbionts in Oligobrachia mashikoi (Siboglinidae, Annelida)
}

\author{
NORIHIRo KUbOTA ${ }^{1}$, MASAAKI KANEMORI ${ }^{1}$, YUICHI SASAYAMA ${ }^{2}$, MASATO AIDA ${ }^{1}$, and YoshiHIRo FUKUMORI ${ }^{1 *}$ \\ ${ }^{1}$ Department of Life Science, Graduate School of Natural Science and Technology, Kanazawa University, \\ Ishikawa 920-1192, Japan \\ ${ }^{2}$ Noto Marine Laboratory, Institute of Nature and Environment Technology, Kanazawa University, \\ Ishikawa, Japan
}

(Received December 26, 2006-Accepted February 8, 2007)

Oligobrachia mashikoi, a frenulata, is a marine invertebrate living in an unusual habitat in Tsukumo Bay (20$25 \mathrm{~m}$ deep), Japan. It lacks a mouth and a gut, and instead possesses specialized cells called bacteriocytes, in which endosymbiotic bacterial cells are kept. The endosymbiosis involves specific interactions and obligatory metabolic exchanges between the host and endosymbiotic bacterial cells. Analyses of 16S rRNA genes from the endosymbiotic cells indicated that there are at least seven phylotypes of endosymbionts in $O$. mashikoi, and these phylotypes are closely related Gammaproteobacteria among which sequence homology was more than $97.6 \%$. The analyses suggested that an adult worm predominantly accommodates one of the seven phylotypes. In situ hybridization targeting 16S rRNA demonstrated that the distribution patterns of the bacterial cells in adult worms were very similar among at least two phylotypes of the endosymbionts. The findings suggest that $O$. mashikoi has a strict selection mechanism for its endosymbiont.

Key words: Oligobrachia mashikoi, endosymbionts, beard worm, 16S rRNA gene, denaturing gradient gel electrophoresis (DGGE)

Siboglinidae polychaetes are long, thin tube-dwelling marine invertebrates harboring endosymbiotic bacteria. Part of the phylum Annelida, Siboglinidae now include Vestimentifera (tubeworm), Frenulata (beard worm), and Monilifera ${ }^{28)}$. Vestimentiferan tubeworms are phylogenetically classified as a sister group of the beard worms ${ }^{13,28,37)}$, and inhabit hydrothermal vents in divergent margins and cold-seeps in convergent margins of the seafloor, where reducing compounds such as sulfides and methane are abundant. On the other hand, beard worms are mainly found in benthic habitats on static seafloors such as continental slopes or deep fjords ${ }^{8,12,31,33,36)}$.

In Tsukumo Bay in Ishikawa Prefecture, Japan, the shallow sea bottom is bathed by a warm current flow. One species of beard worm, Oligobrachia mashikoi, inhabits a

\footnotetext{
* Corresponding author. E-mail address: fukumor@kenroku. kanazawa-u.ac.jp; Tel.: +81-76-264-6231; Fax: +81-76-2646230 .
}

region of this bay ${ }^{15,29)}$. The temperature at the bottom ranges from $9^{\circ} \mathrm{C}$ in winter to $23^{\circ} \mathrm{C}$ in summer. These conditions differ from those in Scandinavia $\left(8-18^{\circ} \mathrm{C}\right)$ where Nordic beard worms are often collected ${ }^{33)}$. The entire body of $O$. mashikoi is covered with chitin tubes 0.2 to $1.0 \mathrm{~mm}$ in diameter and about $400 \mathrm{~mm}$ in length, and sticks in the muddy bottom ${ }^{15}$.

Symbioses between chemoautotrophic bacteria and marine invertebrates were originally discovered at hydrothermal vents in the deep sea ${ }^{7}$, and are reported in more than 200 animal species from at least five different phyla $^{5,11)}$. Beard worms lack a mouth, gut, and anus ${ }^{16,34)}$, and harbor endosymbiotic bacteria in a special tissue called the trophosome ${ }^{32)}$. It is known that tubeworms are dependent on the nutrients supplied by the endosymbiotic bacteria. Analyses of stable carbon isotope ratios and metabolic enzymes indicate that the endosymbionts of tubeworms are mainly sulfur-oxidizing bacteria ${ }^{10,14}$. Although many species of endosymbiotic bacteria have been reported, no one has ever 
been able to isolate and cultivate any endosymbiont of marine invertebrates.

Kimura et al. ${ }^{18)}$ has already reported that the present species harbor symbiotic bacteria in special cells called bacteriocytes in the trophosome. In fact, endosymbiotic bacterial cells were found in bacteriocytes during an electron microscopic analysis ${ }^{9}$. In the present paper, we report that the endosymbionts of $O$. mashikoi are divided into at least seven phylotypes and that adult $O$. mashikoi worms seem to predominantly harbor one phylotype.

\section{Materials and Methods}

\section{Collection of adult O. mashikoi worms}

Adult specimens of Oligobrachia mashikoi were collected with a dredge from the muddy bottom of Tsukumo Bay at a depth of $20-25 \mathrm{~m}$ on Noto Peninsula $\left(37^{\circ} 18^{\prime} 29^{\prime \prime} \mathrm{N}\right.$, $\left.137^{\circ} 14^{\prime} 29^{\prime \prime} \mathrm{E}\right)^{29)}$. Bodies of the worms were carefully taken out of the chitin tubes and washed with autoclaved seawater repeatedly and eventually with $70 \%$ ethanol. The bodies were stored at $-80^{\circ} \mathrm{C}$ until use.

\section{DNA extraction}

Individual trophosome tissues containing endosymbiotic cells were aseptically cut off from the bodies, and homogenized in artificial seawater. Total DNA containing the host's and the endosymbiont's chromosomes were extracted with a Get pure DNA kit for blood (DOJINDO, Kumamoto, Japan) according to the manufacturer's instructions.

\section{Denaturing Gradient Gel Electrophoresis (DGGE)}

A set of eubacterial universal primers (341 fGC and 534r; Table 1) was used to amplify a part of the $16 \mathrm{~S}$ rRNA gene (about $200 \mathrm{bp}$ in length) by PCR. This region contains the $\mathrm{V} 3$ hyper variable region of the gene ${ }^{24)}$. The forward primer, $341 \mathrm{fGC}$, has a 40-nucleotide GC-rich region (GC-clamp) at the 5 ' end which confers stable melting behavior to doublestranded DNA even in the presence of denaturants (urea and formamide $)^{23)}$. The reaction mixture for PCR $(50 \mu \mathrm{l})$ contained $15 \mathrm{mM}$ Tris- $\mathrm{HCl}(\mathrm{pH} 8.3), 50 \mathrm{mM} \mathrm{KCl}, 2.5 \mathrm{mM}$ $\mathrm{MgCl}_{2}, 200 \mu \mathrm{M}$ dNTP, $25 \mathrm{pmol}$ of each primer, $1.25 \mathrm{U}$ of Taq DNA polymerase (Takara, Shiga, Japan), and 10-50 ng of DNA extract from a worm or plasmid DNA. The reaction was run as follows: first, the mixture was incubated for 2 $\min$ at $94^{\circ} \mathrm{C}$. The reaction profile consisted of $1 \mathrm{~min}$ at $94^{\circ} \mathrm{C}$ for denaturation, $1 \mathrm{~min}$ at $65^{\circ} \mathrm{C}$ for annealing, and $2 \mathrm{~min}$ at $72^{\circ} \mathrm{C}$ for elongation. The annealing temperature was gradually decreased by $1^{\circ} \mathrm{C}$ every two cycles until it reached $55^{\circ} \mathrm{C}$, followed by an additional 30 cycles $(50$ cycles in total). Finally, the reaction mixture was incubated for 10 $\min$ at $72^{\circ} \mathrm{C}$. PCR products were subjected to electrophoresis on $2 \%$ agarose gels to confirm their size.

The PCR products were analyzed with the D-Code System (Bio-Rad Laboratories, Hercules, CA, USA) according to the manufacturer's instructions. In brief, PCR products were applied directly onto $10 \%$ polyacrylamide gels with a gradient of denaturants (2.45-4.2 M urea and 14-24\% formamide). Electrophoresis was performed at $200 \mathrm{~V}$ for $18 \mathrm{~h}$ at $58^{\circ} \mathrm{C}$. Gels were stained with ethidium bromide, and gel images were obtained using AE-6905H Image Saver HR (ATTO, Tokyo, Japan). Quantification was done with Multi Gauge software (Fujifilm, Tokyo, Japan).

\section{Phylogenetic analysis}

The bacterial 16S rRNA genes were PCR-amplified by using a pair of eubacterial universal primers (27f and $1525 \mathrm{r}$; Table 1) ${ }^{20)}$ and DNA extracts from $O$. mashikoi trophosome tissues as templates. The reaction mixture for PCR $(20 \mu \mathrm{l})$ contained $10 \mathrm{mM}$ Tris- $\mathrm{HCl}(\mathrm{pH} 8.3), 50 \mathrm{mM} \mathrm{KCl}, 1.5 \mathrm{mM}$ $\mathrm{MgCl}_{2}, 200 \mu \mathrm{M} \mathrm{dNTP}, 12 \mathrm{pmol}$ of each primer, $0.5 \mathrm{U}$ of Taq DNA polymerase (Takara), and 10-50 ng of template DNA. PCR was performed under the following conditions;

Table 1. Oligonucleotide primers used for PCR and DGGE and probes used for in situ hybridization

\begin{tabular}{lll}
\hline Primer name & \multicolumn{1}{c}{ Sequence $\left(5^{\prime}-3^{\prime}\right)$} & \multicolumn{1}{c}{ References } \\
\hline $27 \mathrm{f}$ & AGAGTTTGATCCTGGCTCAG & Lane $(1991)^{20)}$ \\
$1525 \mathrm{r}$ & CAGAAAGGAGGTGATCC & Lane $(1991)^{20)}$ \\
$341 \mathrm{fGC} \S$ & CCTACGGGAGGCAGCAG & Muyzer et al. $(1996)^{24)}$ \\
$534 \mathrm{r}$ & ATTACCGCGGCTGCTGG & Muyzer et al. $(1996)^{24)}$ \\
Anti-mashi & CGCCGCCCUCUGUAUGUA & Deguchi et al. $(2007)^{9)}$ \\
Sense-mashi & UACAUACAGAGGGCGGCG & Deguchi et al. $(2007)^{9)}$ \\
\hline
\end{tabular}

§ For DGGE this primer has the GC-clamp at the 5' end, CGCCCGCCGCGCGCGGCGGGCGGGGCGGGGGCACGGGGGG (Muyzer et al., $1996)^{24)}$. 
the mixture was incubated for $1 \mathrm{~min}$ at $94^{\circ} \mathrm{C}$, followed by 30 cycles consisting of $30 \mathrm{sec}$ at $94^{\circ} \mathrm{C}$ for denaturation, 1 min at $55^{\circ} \mathrm{C}$ for annealing, and $2 \mathrm{~min}$ at $72^{\circ} \mathrm{C}$ for extension. Finally, the mixture was incubated for $5 \mathrm{~min}$ at $72^{\circ} \mathrm{C}$. To reduce bias, we independently conducted several parallel amplifications. The PCR products were confirmed by electrophoresis on $0.7 \%$ agarose gels. The $1.5-\mathrm{kbp}$ products were cloned into the vector pT7Blue (Novagen, Madison, USA), and resulting plasmids were introdued into the Escherichia coli XL-1 Blue strain ${ }^{17)}$. Inserted DNA fragments were sequenced using an ABI PRISM 3100 genetic analyzer (Applied Biosystems, Foster city, CA, USA).

The sequences of the 16S rRNA genes obtained were analyzed using the BLAST program (http:// www.ncbi.nlm.nih.gov/BLAST/) to examine the homology to $16 \mathrm{~S}$ rRNA genes of other bacteria from Gen Bank, EMBL, and DDBJ. Alignment of the 16S rRNA genes was done with CLUSTAL $\mathrm{X}$ software ${ }^{35)}$ and alignment data were edited by the BioEdit Program (http:// www.mbio.ncsu.edu/BioEdit/bioedit.html). The maximum likelihood (ML) analysis was performed using the Dnaml program in the PHYLIP package (http://evolution.gs.washington.edu/phylip.html). The TREE-PUZZLE program (http://www.tree-puzzle.de) computed a discrete gamma distribution of eight variable rate categories for rate-acrosssite variation containing the estimated optimum shape parameter (alpha) and invariable sites. To provide confident estimates for phylogenetic tree topologies inferred by the maximum likelihood analysis, bootstrap analyses (100 times) were employed. Neighbor joining (NJ) and maximum parsimony (MP) analyses were also performed using the Dnadist program, Neighbor program, and Dnapars program included in the PHYLIP package.

\section{Whole-mount in situ hybridization}

Identification of the endosymbiont phylotype by PCR amplification and DNA sequencing experiments using a DNA extract from a small part of a trophosome was carried out to compare the distribution of the endosymbiotic cells in each host worm, before whole-mount in situ hybridization was conducted. The whole-mount in situ hybridization was performed as described elsewhere ${ }^{9)}$. In brief, proteinase $\mathrm{K}$ treated tissues from $O$. mashikoi adults were treated with a sense (Sense-mashi) or anti-sense (Anti-mashi) digoxigenin-labeled RNA probe (Table 1$)^{9}$. The anti-sense probe was designed to detect all seven phylotypes of $O$. mashikoi endosymbionts. The hybridization signals were developed by immunostaining with an anti-digoxigenin antibody which is alkaline phosphatase-conjugated (Roche Diagnos- tics, Mannheim, Germany), and detected by visualization with the coloring substrates of 5-bromo-4-chloro-3-indoyl phosphate and nitro blue tetrazolium.

\section{Nucleotide sequence accession numbers}

The seven established 16S rRNA genes were registered with the DDBJ (accession numbers: AB252051, and AB271120 to AB271125).

\section{Results}

O. mashikoi endosymbionts were classified into at least seven groups

To investigate the homogeneity or heterogeneity of endosymbiotic cells in one adult body of O. mashikoi, a DGGE analysis was carried out. When DNA extracts from a total of 65 adult worms were used in the DGGE analysis, more than six different bands were observed on the gels (Fig. 1). On the other hand, $16 \mathrm{~S}$ rRNA genes $(1.5 \mathrm{kbp})$ were PCR-amplified from all of the 65 DNA extracts using a pair of primers (27f and 1525r; Table 1). When the PCR products were directly sequenced, 62 sequences were classified into seven $16 \mathrm{~S}$ rRNA genes. The remaining three sequences could not be analyzed.

The seven 16S rRNA genes were separately cloned into the pT7Blue vector. The resulting plasmids were called clones 1-7. Using these plasmids as the templates, PCR was carried out. When the PCR products were analyzed in the DGGE experiment, six discrete DNA bands appeared on the gel (Fig. 2). Five of seven PCR products showed individual mobility (lanes 2, 3, 4, 5 and 7 in Fig. 2). DNA fragments from clone 5 (lane 6) and clone 7 (lane 8) showed the same

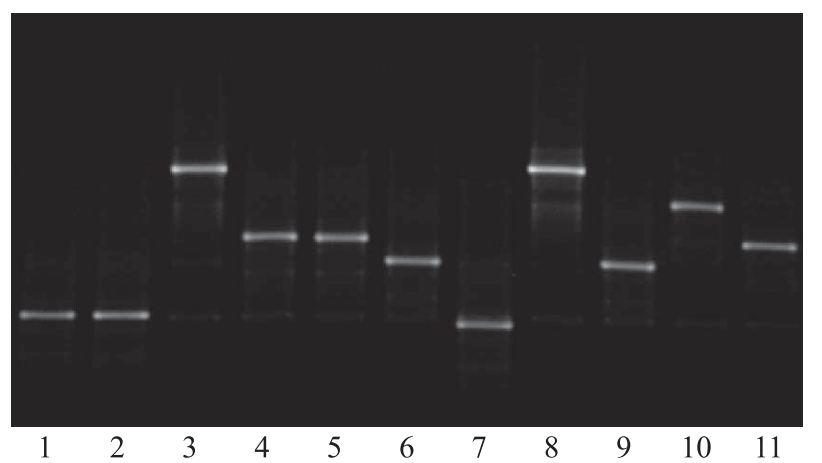

Fig. 1. DGGE analysis of $O$. mashikoi endosymbionts. Each lane represents a DGGE band pattern of DNA extract obtained from one host worm. The gel profiles of eleven of 65 worms are shown. Bands observed were divided into six groups; group 1: lanes 1 and 2, group 2: lanes 3 and 8, group 3: lanes 4, 5 and 11, group 4: lanes 6 and 9, group 5: lane 7, group 6: lane 10 . 


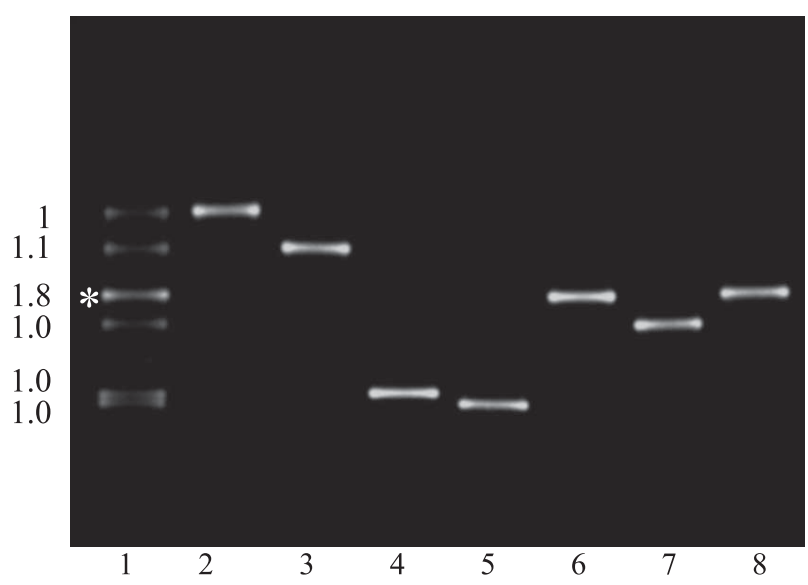

Fig. 2. DGGE analysis of $16 \mathrm{~S}$ rRNA genes cloned on plasmids. The seven plasmids (named clones 1-7) carrying different 16S rRNA genes from the $O$. mashikoi endosymbionts were used as templates and the PCR products were analyzed by DGGE. Plasmids used were as follows; lane 1: all seven plasmids; lane 2: clone 1 (endosymbiont A), lane 3: clone 2 (endosymbiont B), lane 4: clone 3 (endosymbiont $\mathrm{C}$ ), lane 5: clone 4 (endosymbiont $\mathrm{D}$ ), lane 6: clone 5 (endosymbiont E), lane 7: clone 6 (endosymbiont F), lane 8: clone 7 (endosymbiont G). The band marked with an asterisk contained two PCR products. Numbers on the left show the relative intensity of each band in lane 1 . The numbers are means calculated from two experiments.

mobility. This is due to only one base substitution in the region used in the DGGE analysis. When the seven plasmids were mixed at equal concentrations and the mixture was used as the template, five of the six bands had nearly the same fluorescence intensity, and the remaining band marked with an asterisk containing two DNA fragments had high intensity (lane 1 in Fig. 2). This band was about 1.8 times more intense than the uppermost band in lane 1 (Fig. 2). This result indicated that the band intensity reflected the molar ratio among the templates under the conditions used. As shown in Fig. 1, one major band was detected in each lane, strongly suggesting that each DNA extract mainly contained one sequence of the 16S rRNA gene, and, in turn, that one phylotype of endosymbiont is predominantly harbored in one adult worm. We speculated that the seven $16 \mathrm{~S}$ rRNA sequences correspond to the seven phylotypes of endosymbionts, and tentatively named the respective bacte- ria endosymbionts A-G. Host worms harboring endosymbiont $\mathrm{A}$ were most common among the 65 individuals (Table 2). Since we could not clearly determine sequences of 16S rRNA genes from three of 65 DNA extracts, we classified these three as 'others'.

To confirm the sequences of the seven 16S rRNA genes from the $O$. mashikoi endosymbionts, the 16S rRNA genes $(1.5 \mathrm{kbp})$ which were amplified from 17 of 65 DNA extracts (nine included the 16S rRNA gene from endosymbiont A, one from endosymbiont $\mathrm{B}$, one from endosymbiont $\mathrm{C}$, three from endosymbiont $\mathrm{D}$, one from endosymbiont $\mathrm{E}$, one from endosymbiont $F$, and one from endosymbiont $G$ ) were cloned and sequenced. About ten clones were sequenced in each DNA extract, and only one gene sequence was found in each DNA extract. In nine DNA extracts which contained the 16S rRNA gene from endosymbiont A, other 16S rRNA genes were not obtained. This result supports the idea that the seven 16S rRNA genes obtained are from seven distinct endosymbionts, not from a single endosymbiont which has multiple copies of the rRNA gene. Although the DGGE analyses suggested that more than two phylotypes of endosymbionts might exist in one $O$. mashiko $i$ adult (e.g. lanes 3 and 8 in Fig. 1), one phylotype was predominantly harbored in one adult worm. Using the respective DNA extracts, $18 \mathrm{~S}$ rRNA genes of $O$. mashikoi were PCR-amplified and directly cloned into the pT7Blue plasmid vector, and then the inserted DNA fragments were sequenced. All sequences exactly coincided with the previously reported sequence of the O. mashikoi 18S rRNA gene (accession number: $\mathrm{AB} 057750)^{18}$. This result indicated that host worms collected in this study were the same species, although they harbored different endosymbionts.

The extent of the nucleotide sequence variation among the seven rRNA genes was relatively small $(\leq 2.4 \%$; Table 3 ). While the nucleotide substitutions between the $O$. mash$i k o i$ endosymbionts and other bacteria ubiquitously spread in the 16S rRNA gene, differences among the $O$. mashikoi endosymbionts reside in the hyper variable regions, especially the V3 region (Fig. 3). Kimura et al. reported the sequence of the 16S rRNA gene of an $O$. mashikoi endosymbiont (accession number: AB057751) ${ }^{18}$. As shown in Fig. 3, the sequence for the V3 region suggests the endo-

Table 2. Classification of $O$. mashikoi endosymbiont phylotypes on the basis of the DGGE analysis. Each column shows the number and percentage of host worms harboring the respective endosymbiont. The seven phylotypes correspond to sym A-sym $\mathrm{G}$

\begin{tabular}{cccccccccc}
\hline & sym A & sym B & sym C & sym D & sym E & sym F & sym G & Others & Total \\
\hline & 26 & 4 & 2 & 9 & 10 & 4 & 7 & 3 & 65 \\
$\%$ & 40.0 & 6.2 & 3.1 & 13.8 & 15.4 & 6.2 & 10.7 & 4.6 & 100 \\
\hline
\end{tabular}


Table 3. Homology among the 16S rRNA genes of $O$. mashikoi endosymbionts. Regions containing ambiguous alignments, gaps, insertions and deletions were removed and a length of $1122 \mathrm{bp}$ was utilized in the analysis

\begin{tabular}{llllllll}
\hline & & 1 & 2 & 3 & 4 & 5 & 6 \\
\hline 1 & Endosymbiont A & & & & & & \\
2 & Endosymbiont B & 98.6 & & & & & \\
3 & Endosymbiont C & 97.6 & 98.6 & & & & \\
4 & Endosymbiont D & 97.8 & 98.4 & 99.2 & & & \\
5 & Endosymbiont E & 98.0 & 98.6 & 99.4 & 99.8 & & 99.2 \\
6 & Endosymbiont F & 97.9 & 98.9 & 99.1 & 99.0 & 99.1 & \\
7 & Endosymbiont G & 97.9 & 98.7 & 99.3 & 99.3 & 99.5 & \\
\hline
\end{tabular}

Endosymbiont-A
Endosymbiont-B
Endosymbiont-C
Endosymbiont-D
Endosymbiont-E
Endosymbiont-F
Endosymbiont-G
O. mashikoi SYM

Endosymbiont-A Endosymbiont-B Endosymbiont-C Endosymbiont-D Endosymbiont-E Endosymbiont-F Endosymbiont-G O. mashikoi SYM

368

TGGACAATGGGGGCAAC C C T GAT TCAGCAAT G C C G C G T G T G T GAAGAAGG C C C A G G G T T

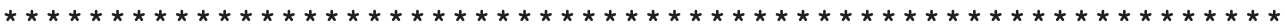

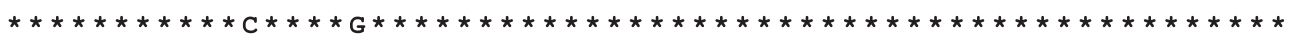

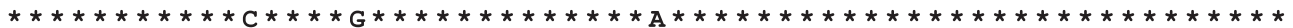

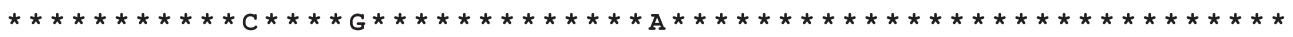

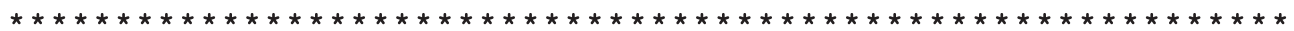

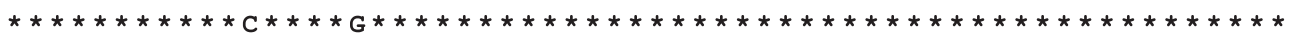

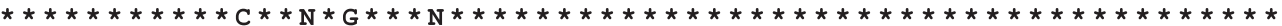

GTAAAGCACT TTCAATTGTGAAGAAAAGATCAAGATTAAT ACTCTTGGTC T T GACGTTA

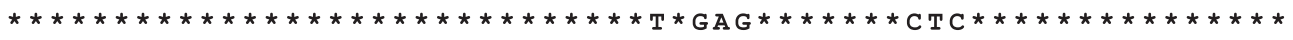

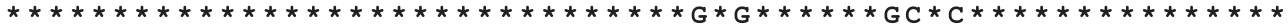

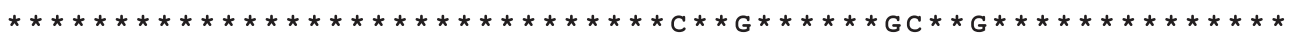

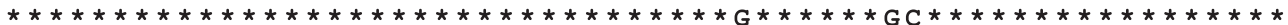

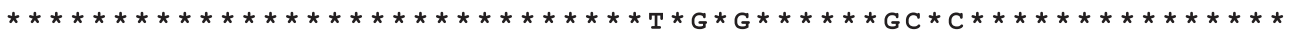

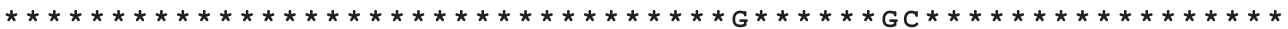

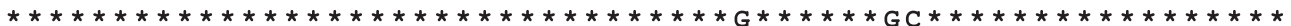

Fig. 3. Alignment of a portion of $16 \mathrm{~S}$ rRNA genes from the seven present phylotypes and the previously reported sequence ${ }^{18)}$ of $O$. mashikoi endosymbionts. The sequences shown correspond with the V3 hyper variable region of the 16S rRNA gene. Asterisks mean nucleotides identical with endosymbiont A. The nucleotide numbers correspond to the $16 \mathrm{~S}$ rRNA gene of E. coli (accession number: U00096). N: not identified.

symbiont reported by Kimura et al. to be related with endosymbiont G. However, it should be noted that the 16S rRNA sequence (accession number: AB057751) has many unidentified nucleotides (39 unidentified in 1508 base pairs). Therefore, it is very hard to discuss the relationship between the endosymbiont reported by Kimura et al. and the endosymbionts A-G identified in the present study.

\section{The seven endosymbionts of $\mathrm{O}$. mashikoi formed a monophyletic group}

Using the sequencing data on the 16S rRNA genes, a phylogenetic tree was constructed by the maximum likelihood method (Fig. 4). The results showed that the O. mashikoi endosymbionts are within the Gammaproteobacteria, in which many thioautotrophic and methanotrophic symbionts of marine invertebrates are included. Phylogenetic analysis indicates that the seven phylotypes of $O$. mashikoi endosymbionts form a monophyletic group (Fig. 4). The $16 \mathrm{~S}$ rRNA genes of the $O$. mashikoi endosymbionts showed the highest homology to that of the uncultured bacterium clone Belgica 2005/10-140-13 (96.7-97.2\% homology) living in heavy-metal-containing North Sea surface sediments (Fig. 4). These are also related to the environmental clones AT-s43 (95.4-96.7\% homology) taken from a hydrothermal area at the Mid-Atlantic Ridge, and JTB35 (92.1-92.7\% homology) taken from the Japan Trench. These clones were taken from hydrothermal or cold seep areas. The phylogenetic analysis indicated that the $O$. mashikoi endosymbionts are not closely related to the endosymbionts of marine invertebrates such as Bathymodiolus japonicus (90.7-91.4\% homology) and Riftia pachyptila (92.1-92.7\% homology) (Fig. 4). Neighbor joining (NJ) and maximum parsimony (MP) analyses gave a similar topology to that of the maximum likelihood tree (data not shown). 


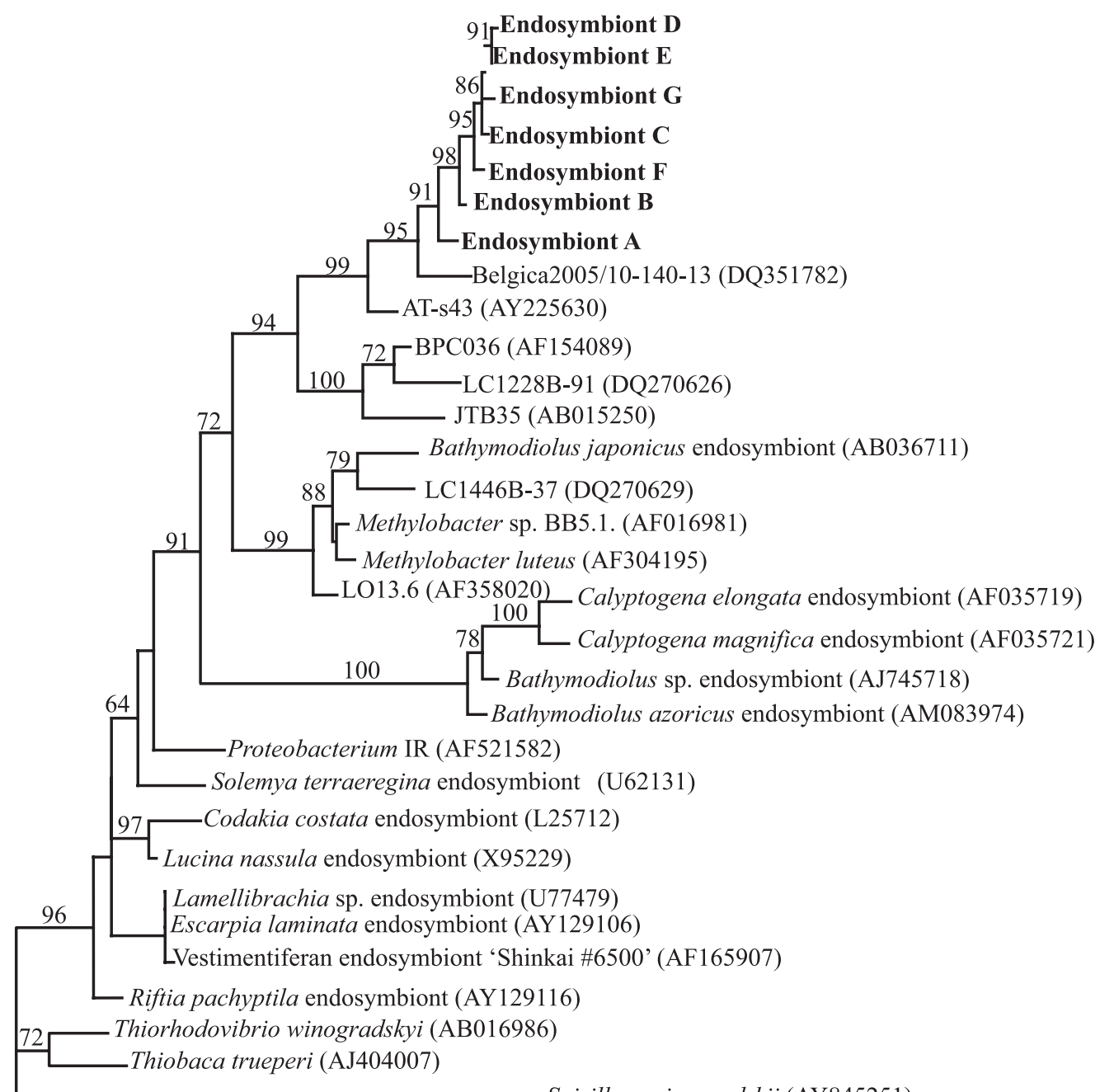

Spirillum winogradskii (AY845251)

0.1

Fig. 4. Phylogenetic tree of 16S rRNA genes. Sequences of 16S rRNA genes from O. mashikoi endosymbionts and other free-living or endosymbiotic bacteria within the Gammaproteobacteria were analyzed with the maximum likelihood method. Spirillum winogradskii was used as an outgroup. The accession numbers for the reference sequences used are shown in parentheses. The scale bar is equal to 0.1 nucleotide substitutions per sequence position. The percentage of 100 bootstrap resamplings is shown at each branch. Bootstrap values are shown for nodes supported in $>50$ of 100 trees.

\section{Distribution of the endosymbiotic cells in the adult O. mashikoi body was very similar among the endosymbionts.}

The distribution of the endosymbiotic cells in the adult $O$. mashikoi body had been investigated by whole-mount in situ hybridization"), and the cells found to be localized to the posterior part of the body, or the trophosome, in which they are maintained in irregular structures protruding from both sides of the ventral vessel toward the dorsal vessel, like ferny leaves or ribs of vertebrates. Since we had not identi- fied the phylotype of endosymbionts previously, we tried to compare the distribution patterns among the endosymbionts in the present study. We attempted a fluorescence in situ hybridization (FISH) analysis to separately detect the seven phylotypes, but were unsuccessfl, because $O$. mashikoi had high background auto-fluorescence as described before ${ }^{18}$. Since one host adult seemed to mainly harbor only one endosymbiont, we did not need to prepare several different probes. Therefore, the distribution was examined using digoxigenin-labeled probe which recognized all seven phylotypes of the 16S rRNA genes. After identification of an 
A

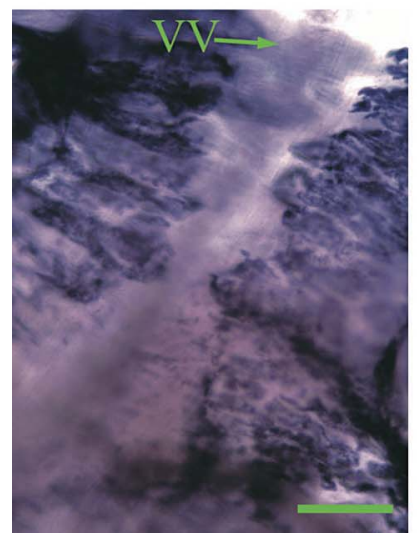

B

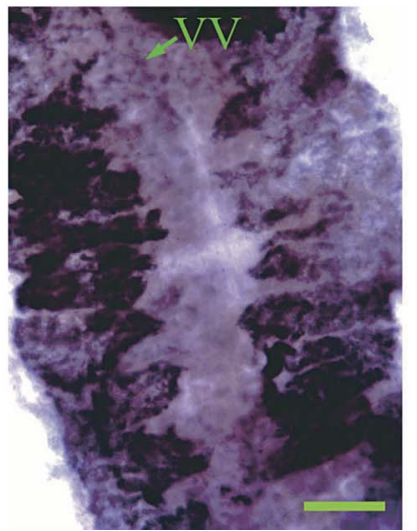

C

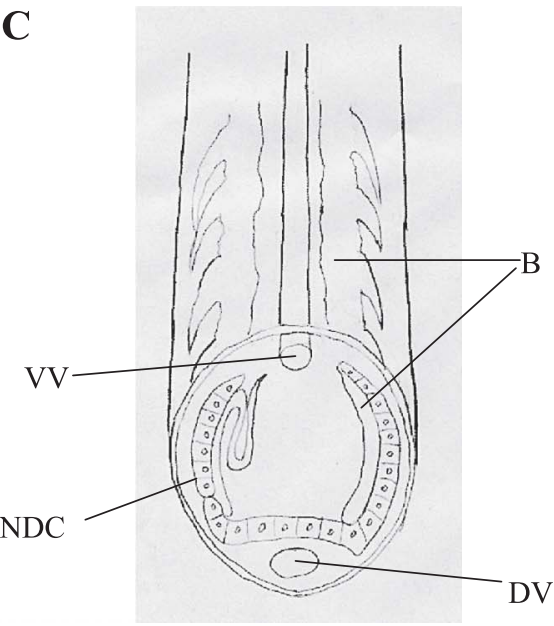

Fig. 5. Whole-mount in situ hybridization of dissected post-annular regions of $O$. mashikoi. The tissues harboring endosymbiont A (A) and B (B) were examined. (C) Schematic diagram of the trophosome in O. mashikoi. These figures and the diagram show the view from the ventral side of the trophosome. B: Bacteriocytes, DV: Dorsal Vessel, NDC: Nutrient Deposit Cells, VV: Ventral Vessel. Scale bar, $100 \mu \mathrm{m}$.

endosymbiont phylotype as mentioned in Materials and Methods, the distribution of the endosymbiotic cells was determined. The distribution patterns of the cells containing endosymbiont $\mathrm{A}$ and $\mathrm{B}$ shown in Fig. 5 were almost the same as described previously ${ }^{9}$ (Fig. 5).

\section{Discussion}

This study suggests that there are at least seven distinct, but closely related, phylotypes in O. mashikoi endosymbionts. Furthermore, only one of these phylotypes seems to predominate in an adult worm. In the vestimentiferan tubeworms, host adults from different habitats harbor different endosymbionts $^{22,25)}$. However, all adults of $O$. mashikoi were collected at one sampling station, the area of which is about 100 square meters in Tsukumo Bay (48.6 hectares). We know of no report concerning the high diversity of closely related endosymbionts in a marine invertebrate which inhabits a small area.

The phylogenetic analysis of $16 \mathrm{~S}$ rRNA genes indicates that the seven phylotypes of $O$. mashikoi endosymbionts are related to the environmental clones (Fig. 4). However, we could not infer the nutrient source of the endosymbionts from the phylogenetic analysis. Kimura et al. ${ }^{18)}$ reported that the $O$. mashikoi endosymbiont might be a methanotrophic bacterium. However, they did not detect methane monooxygenase genes ( $p m o A$ and $m m o X$ ) by PCR, although a RuBisCO gene was detected in the $O$. mashikoi trophosome ${ }^{18)}$. Furthermore, the intracytoplasmic-stacked membranes specifying methanotrophic bacterium ${ }^{6,21)}$ have not been observed in the endosymbiotic cells of $O$. mashikoi by electron microscopy ${ }^{9}$. Therefore, it seems likely that the O. mashikoi endosymbionts would be chemoautotrophic bacteria. This is consistent with the idea that the extracellular giant hemoglobin in blood vessels of $O$. mashikoi conveys sulfides to its endosymbiont like Riftia pachyptila ${ }^{1,2,26)}$, and the fact that sulfide is detected in the sediment where $O$. mashikoi inhabits ${ }^{30}$.

There are two pathways by which endosymbionts are transmitted: horizontal transmission which involves the spread of the symbionts between contemporary hosts or reinfection by bacteria in the environment in each generation of animals, and vertical transmission which is the transfer of symbionts from parents to their offspring. Vertical transmission of bacterial endosymbionts occurs in several species of marine invertebrates ${ }^{4,19}$. In a vestimentiferan tubeworm Riftia pachyptila, however, endosymbionts were not found in the eggs or ovaries ${ }^{3)}$. Recently, Nussbaumer et al. ${ }^{27)}$ reported that the endosymbiotic bacterial cells of some tubeworms enter the host's tissue through its skin from the surrounding environment. If $O$. mashikoi acquires its endosymbiont by re-infection, it might have a mechanism to predominantly take in one out of the several endosymbionts. Furthermore, the proportion of endosymbionts observed in $O$. mashikoi adults as shown in Table 2 might reflect the proportion of free-living endosymbionts living in the environment. We are now investigating the free-living endosymbionts in the sediment of Tsukumo Bay. The results may provide some clues as to how endosymbionts are acquired in O. mashikoi. 


\section{Acknowledgements}

We wish to thank K. Yamaguchi for the sequencing analysis, K. Ishida for the phylogenetic analysis, and M. Matada for helping with the collection of $O$. mashikoi.

\section{References}

1) Arp, A.J., and J.J. Childress. 1983. Sulfide binding by the blood of the hydrothermal vent tube worm Riftia pachyptila. Science. 219:295-297.

2) Arp, A.J., J.J. Childress, and R.D. Vetter. 1987. The sulphidebinding protein in the blood of the vestimentiferan tube-worm, Riftia pachyptila, is the extracellular hemoglobin. J. Exp. Biol. 128:139-158.

3) Cary, S.C., W. Warren, E. Anderson, and S.J. Giovannoni. 1993. Identification and localization of bacterial endosymbionts in hydrothermal vent taxa with symbiont-specific polymerase chain reaction amplification and in situ hybridization techniques. Mol. Mar. Biol. Biotechnol. 2:51-62.

4) Cary, S.C. 1994. Vertical transmission of a chemoautotrophic symbiont in the protobranch bivalve, Solemya reidi. Mol. Mar. Biol. Biotechnol. 3:121-130.

5) Cavanaugh, C.M. 1994. Microbial symbiosis: patterns of diversity in the marine environment. Am. Zool. 34:79-89.

6) Cavanaugh, C.M., C.O. Wirsen, and H.W. Jannasch. 1992. Evidence for methylotrophic symbionts in a hydrothermal vent mussel (Bivalvia: Mytilidae) from the mid-atlantic ridge. Appl. Environ. Microbiol. 58:3799-3803.

7) Corliss J.B., and R.D. Ballard. 1977. Oasis of life in the cold abyss. Natl. Geogr. Mag. 152:441-453.

8) Dando, P.R., L. Bussmann, S.J. Niven, S.C.M. O'Hara, R. Schmaljohann, and L.J. Taylor. 1994. A methane seep area in the Skagerrak, the habitat of the pogonophore Siboglinum poseidoni and the bivalve mollusc Thyasira sarsi. Mar. Ecol. Prog. Ser. 107:157-167.

9) Deguchi, M., K. Kubota, A. Matsuno, M. Kanemori, Y. Fukumori, and Y. Sasayama. 2007. Actual distribution of bacteriocytes in the trophosome of a beard worm (Oligobrachia mashikoi, Siboglinidae, Annelida): clarification using whole-mount in situ hybridization. Acta. Zool. 88:129-135.

10) Felbeck, H. 1981. Chemoautotrophic potential of the hydrothermal vent tube worm, Riftia pachyptila Jones (Vestimentifera). Science. 213:336-338.

11) Fisher, C.R. 1990. Chemoautotrophic and methanotrophic symbioses in marine invertebrates. Rev. Aquat. Sci. 2:399-436.

12) Flügel, H.J., and I. Langhof. 1983. A new hermaphroditic pogonophore from the Skagerrak. Sarsia. 68:131-138.

13) Halanych, K.M. 2005. Molecular phylogeny of siboglinid annelids (a.k.a. pogonophorans): a review. Hydrobiologia. 535/ 536:297-307.

14) Hand, S.C. 1987. Trophosome ultrastructure and the characterization of isolated bacteriocytes from invertebrate-sulfur bacteria symbioses. Biol. Bull. 173:260-276.

15) Imajima, M. 1973. A new species of the genus Oligobranchia (pogonophora) collected from Tsukumo Bay, Noto Peninsula. Ann. Rep. Noto. Mar. Lab. 13:7-12.

16) Ivanov, A.V. 1963. Pogonophora. p. 479. Academic Press, London.
17) Jerpseth, B., A. Greener, J.M. Short, J. Viola, and P.L. Kretz. 1992. XL1-Blue MRF' E. coli cells: McrA-, McrCB-, McrF-, Mrr-, HsdR-derivative of XL1-Blue cells. Strategies. 5:81-83.

18) Kimura, H., M. Sato, Y. Sasayama, and T. Naganuma. 2003. Molecular characterization and in situ localization of endosymbiotic 16S ribosomal RNA and RuBisCO genes in the pogonophoran tissue. Mar. Biotechnol. 5:261-269.

19) Krueger, D.M., R.G. Gustafson, and C.M. Cavanaugh. 1996. Vertical transmission of chemoautotrophic symbionts in the bivalve Solemya velum (Bivalvia: Protobranchia). Biol. Bull. 190:195202.

20) Lane, D.J. 1991. 16S/23S rRNA sequencing. pp. 115-175. In E. Stackebrandt, and M. Goodfellow (ed.), Nucleic acid techniques in bacterial systematics. John Wiley and sons, New York.

21) Lidstrom, M.E. 1992. The aerobic methylotrophic bacteria. pp. 431-445. In A. Balows, H.G. Trüper, M. Dworkin, W. Harder, and K.H. Schleifer (ed.), The prokaryotes, Springer-Verlag, New York.

22) McMullin, E.R., S. Hourdez, S.W. Schaeffer, and C.R. Fisher. 2003. Phylogeny and biogeography of deep sea vestimentiferan tubeworms and their bacterial symbionts. Symbiosis. 34:1-41.

23) Muyzer, G., E.C. De-waal, and A.G. Uitterlinden. 1993. Profiling of complex microbial populations by denaturing gradient gel electrophoresis analysis of polymerase chain reaction-amplified genes coding for 16S rRNA. Appl. Environ. Microbiol. 59:695700.

24) Muyzer, G., S. Hottentrager, A. Teske, and C. Wawer. 1996. Denaturing gradient gel electrophoresis of PCR-amplified 16S rDNA. A new molecular approach to analyze the genetic diversity of mixed microbial communities. p. 3.4.4.1-3.4.4.23. In A.D.L. Akkermans, J.D. van Elsas, and F.J. de Bruijn (ed.), Molecular microbial ecology manual, Kluwer Academic Publishing, Dordrecht, Netherlands.

25) Nelson, K., and C.R. Fisher. 2000. Absence of cospeciation in the deep-sea vestimentiferan tubeworms and their bacterial endosymbionts. Symbiosis. 28:1-15.

26) Numoto, N., T. Nakagawa, A. Kita, Y. Sasayama, Y. Fukumori, and K. Miki. 2005. Structure of an extracellular giant hemoglobin of the gutless beard worm Oligobrachia mashikoi. Proc. Natl. Acad. Sci. 102:14521-14526.

27) Nussbaumer, A.D., C.R. Fisher, and M. Bright. 2006. Horizontal endosymbiont transmission in hydrothermal vent tubeworms. Nature. 441:345-348.

28) Rouse, G.W. 2001. A cladistic analysis of Siboglinidae Caullery, 1914 (Polychaeta, Annelida): formerly the phyla Pogonophora and Vestimentifera. Zool. J. Linn. Soc. 132:55-80.

29) Sasayama, Y., M. Matada, Y. Fukumori, M. Umebayashi, A. Matsuno, T. Nakagawa, and M. Imajima. 2003. External morphology of the posterior end, the "Opisthosoma", of the beard worm Oligobrachia mashikoi (Pogonophora). Zool. Sci. 20:1411-1416.

30) Sasayama, Y., Y. Higashide, M. Sakai, M. Matada, and Y. Fukumori. 2007. Relationship between the lifestyle of a Siboglinidae polychaete, Oligobrachia mashikoi (also known as Pogonophora), and the total sulfide/nitrogen levels in its habitat. Zool. Sci. 24:131-136.

31) Southward, A.J., and E.C. Southward. 1963. Notes on the biology of some Pogonophora. J. Mar. Biol. Assoc. UK. 43:57-64.

32) Southward, A.J., E.C. Southward, P.R. Dando, G.H. Rau, H. Felbeck, and H. Flügel. 1981. Bacterial symbionts and low 13C/12C 
ratios in tissues of pogonophora indicate unusual nutrition and metabolism. Nature. 293:616-619.

33) Southward, E.C. 1971. Pogonophora of the northwest Atlantic: Nova Scotia to Florida. Smithsonian. Contrib. Zool. 88:1-29.

34) Southward, E.C. 1978. Description of a new species of Oligobrachia (Pogonophora) from the North Atlantic, with a survey of the Oligobrachiidae. J. Mar. Biol. Assoc. U.K. 58:357-366.

35) Thompson, J.D., T.J. Gibson, F. Plewniak, F. Jeanmougin, and
D.G. Higgins. 1997. The CLUSTAL X windows interface: flexible strategies for multiple sequence alignment aided by quality analysis tools. Nucleic. Acids. Res. 25:4876-4882.

36) Webb, M. 1964. A redescription of Siboglinum ekmani JÄGERSTEN (Pogonophora). Sarsia. 15:37-47.

37) Winnepenninckx, B., T. Backeljau, and R.D. Wachter. 1995. Phylogeny of protostome worms derived from 18S rRNA sequences. Mol. Biol. Evol. 12:641-649. 